\title{
Differences in plankton community structure along the Godthåbsfjord, from the Greenland Ice Sheet to offshore waters
}

\author{
Kristine Engel Arendt ${ }^{1, *}$, Torkel Gissel Nielsen ${ }^{2,4}{ }^{\text {, Søren Rysgaard }}{ }^{1}$, Kajsa Tönnesson ${ }^{3}$ \\ ${ }^{1}$ Greenland Climate Research Centre, Greenland Institute of Natural Resources, PO Box 570, Kivioq 2, 3900 Nuuk, Greenland \\ ${ }^{2}$ National Environmental Research Institute, Department of Marine Ecology, University of Aarhus, Frederiksborgvej 399, \\ 4000 Roskilde, Denmark \\ ${ }^{3}$ Department of Marine Ecology - Göteborg, University of Gothenburg, Box 461, 40530 Göteborg, Sweden \\ ${ }^{4}$ Present address: National Institute of Aquatic Resources, DTU Aqua, Section for Ocean Ecology and Climate, \\ Technical University of Denmark, Kavalergården 6, 2920 Charlottenlund, Denmark
}

\begin{abstract}
This study describes differences in plankton community structure and in chemical and physical gradients between the offshore West Greenland Current system and inland regions close to the Greenland Ice Sheet during the post-bloom in Godthåbsfjorden $\left(64^{\circ} \mathrm{N}, 51^{\circ} \mathrm{W}\right)$. The offshore region had pronounced vertical mixing, with centric diatoms and Phaeocystis spp. dominating the phytoplankton, chlorophyll (chl) a (0.3 to $3.9 \mathrm{\mu g} \mathrm{l}^{-1}$ ) was evenly distributed and nutrients were depleted in the upper $50 \mathrm{~m}$. Ciliates and heterotrophic dinoflagellates constituted equal parts of the protozooplankton biomass. Copepod biomass was dominated by Calanus spp. Primary production, copepod production and the vertical flux were high offshore. The water column was stratified in the fjord, causing chl a to be concentrated in a thin sub-surface layer. Nutrients were depleted above the pycnocline, and Thalassiosira spp. dominated the phytoplankton assemblage close to the ice sheet. Dinoflagellates dominated the protozooplankton biomass, whereas copepod biomass was low and was dominated by Pseudocalanus spp. and Metridia longa. Primary production was low in the outer part of the fjord but considerably higher in the inner parts of the fjord. Copepod production was exceeded by protozooplankton production in the fjord. The results of both physical/chemical factors and biological parameters suggest separation of offshore and fjord systems.
\end{abstract}

KEY WORDS: West Greenland coast - Sub-Arctic fjord · Physical gradients - Plankton community structure $\cdot$ Primary and secondary production $\cdot$ Vertical flux

Resale or republication not permitted without written consent of the publisher

\section{INTRODUCTION}

West Greenland marine ecosystems present a complex interaction between the marine areas along the West Greenland banks and the numerous fjords that drain melt water from the Greenland Ice Sheet to the sea. The freshwater discharge from land creates a gradient in freshwater content from the inner parts of the fjord systems to the shelf area dominated by the relatively warm and saline West Greenland Current. The mixing of water masses of distinct origin creates a highly productive system (Smidt 1979) sustaining a rich and diverse food web. Whales (Heide-Jørgensen et al. 2007) and seals feed here during summer, and seabirds from the entire Baffin Bay find their winter habitat in this ice-free area (Merkel et al. 2002). Furthermore, the area is important for the Greenland society, in terms of commercial fishing as well as traditional and recreational fishing and hunting.

Copepods are key organisms responsible for the transfer of carbon from the primary producers and microzooplankton to higher trophic levels. In the Arctic, Calanus spp. play an important role because of their ability to effectively convert phytoplankton and accumulate lipids (Falk-Petersen et al. 2007). The importance of Calanus spp. is well documented in the shelf and offshore region of West Greenland (Pedersen \& Smidt 2000, Munk et al. 2003). It has been shown 
that circulation of the north-flowing current around the West Greenland banks creates eddies that retain plankton in high biomass patches (Pedersen et al. 2005). In the shelf and offshore area, Calanus leave the surface water in mid-summer, after which smaller species and juvenile stages of copepods dominate the mesozooplankton biomass (Thor et al. 2005, Møller et al. 2006). Simultaneously, a significant biomass of protozooplankton builds up (Levinsen \& Nielsen 2002), which, together with the small species and copepod stages, is responsible for recycling the primary production in an extended period of time. It has been shown that plankton community structure in the shelf area is dependent on depth and time (Thor et al. 2005), but the interaction between the fjords and offshore plankton communities is currently unknown. Furthermore, it is not known whether the succession dynamics of offshore plankton communities are representative of the inner fjord systems, as advection of zooplankton could determine the plankton community structure in the fjord, or whether the plankton composition represents an isolated community adapted to the microhabitat in the fjord, as suggested by Smidt (1979).

Due to global climate change, acceleration of mass loss of the Greenland Ice Sheet has been observed (Velicogna \& Wahr 2006, Hanna et al. 2008). In addition, precipitation has been predicted to increase during the next decade (Kattsov \& Källén 2005). Increased runoff from the ice sheet and surrounding land to the inner parts of the fjord would greatly affect the water column structure and thereby the microhabitat in the fjord and coastal regions. The enhanced admission of freshwater could potentially enhance estuarine circulation and thereby nutrient input to the inner parts of the fjord (Rysgaard et al. 2003, Bendtsen et al. 2007). Entrainment of nutrient-rich deep water into the photic zone of the inner fjord would result in increased biological productivity (Aure et al. 2007, Rysgaard \& Glud 2007) and would most likely affect the energy flow through the entire food web. Furthermore, changes in the West Greenland Current are an important factor determining the characteristics of the pelagic system. A general warming has been found to occur in the central parts of Baffin Bay (Zweng \& Münchow 2006) and along the West Greenland coast (Holland et al. 2008). Changes in the water mass circulation in the North Atlantic and Arctic areas are known to determine the distribution and relationship between the important Calanus species (Fleminger \& Hulsemann 1977, Hirche 1991), but the extent to which it determines the mesozooplankton community in the West Greenland fjords remains unknown.

The coastal ecosystem is still inadequately understood, and it is not yet described how the ecosystem and its organisms adapt to the variability of climate gradients. Long-term monitoring data are lacking, and a more comprehensive understanding of the system is needed in order to make predictions of how global climate change will affect the ecosystem and its productivity. The aim of the present study was to describe how the plankton community structure and productivity and the vertical flux vary in relation to differences in the physical/chemical gradients from the offshore area and along the fjord to the Greenland Ice Sheet and to initiate a long-term monitoring program in West Greenland waters (Rysgaard et al. 2008).

\section{MATERIALS AND METHODS}

Study site and sampling. This study was conducted along a section from the inner parts of Godthåbsfjorden close to the Greenland Ice Sheet along the fjord to the offshore parts of the Fyllas Banke (Fig. 1). Samples were collected from RV 'Adolf Jensen' (Greenland Institute of Natural Resources) in the daytime (07:00 to 21:00 h) from 15 to 20 May 2006.

Vertical profiles of water temperature, salinity, density and fluorescence were obtained using a CTD (SBE 19plus, SeaCat) equipped with a Seapoint Chlorophyll Fluorometer and a Biospherical/Licor sensor. Profiles were recorded from the surface to approximately $5 \mathrm{~m}$ above the bottom. Water samples were taken using a 51 Niskin water sampler at depths of 1, 5, 10, 15, 20,30, $50,100,200,400,600,800 \ldots \mathrm{m}$, with the deepest sample being collected $10 \mathrm{~m}$ above the bottom.

Water chemistry. Water samples $(10 \mathrm{ml})$ were $\mathrm{GF} / \mathrm{C}$ filtered and kept frozen $\left(-18^{\circ} \mathrm{C}\right)$ until analyses for nutrients. Concentrations of $\mathrm{NO}_{2}^{-}+\mathrm{NO}_{3}{ }^{-}$were measured by vanadium chloride reduction (Braman \& Hendrix 1989). Phosphate and $\mathrm{SiO}_{2}$ concentrations were analysed using standard spectrophotometric methods (Strickland \& Parsons 1972, Grasshoff et al. 1983). At each station, water samples from 5, 30 and $50 \mathrm{~m}$ depth were taken for chlorophyll a (chl a) measurements. The samples were split into 3 subsamples of $150 \mathrm{ml} ; 2$ samples were passed through $11 \mu \mathrm{m}$ and $40 \mu \mathrm{m}$ filters, while 1 sample remained untreated until the samples were filtered onto GF/C filters $(<0.2 \mathrm{bar})$ and frozen $\left(-18^{\circ} \mathrm{C}\right) . \mathrm{Chl}$ a samples were extracted in $96 \%$ ethanol for $18 \mathrm{~h}$ before fluorescence was measured on a fluorometer (TD-700, Turner Designs) calibrated against a pure chl a standard (Turner Designs). The analysis was used for calibration of the CTD fluorometer, and chl a concentrations were then calculated from CTD fluorescence profiles at all stations.

Phytoplankton biomass and primary production. Net phytoplankton was sampled by triplicate vertical hauls using a $20 \mu \mathrm{m}$ plankton net (0 to $60 \mathrm{~m})$, and the phytoplankton composition was identified to major 


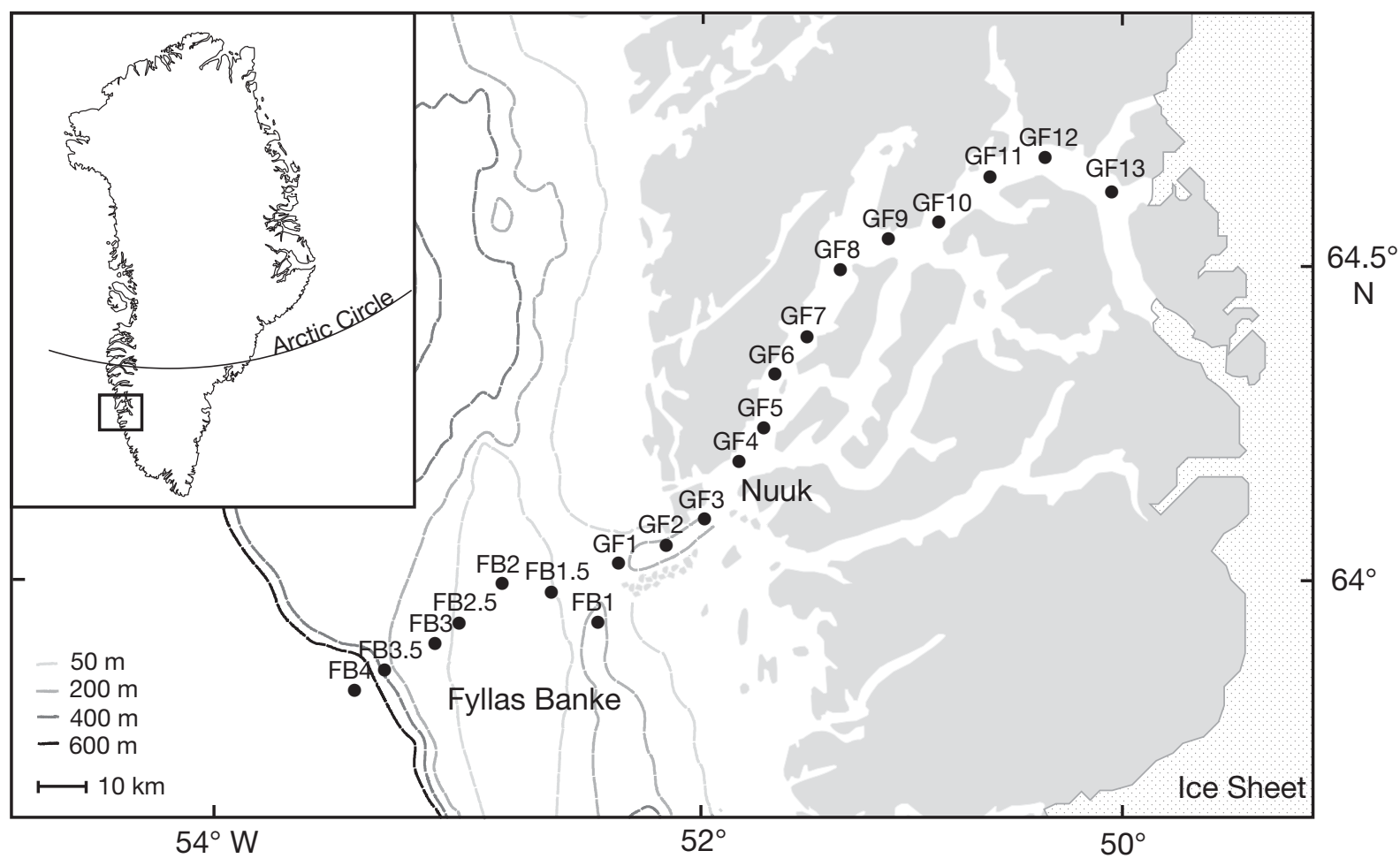

Fig. 1. Sampling locations in the Godthåbsfjord and at Fyllas Banke, West Greenland

taxonomical groups at the Arctic Agency, Poland. The phytoplankton biomass (chl $a$ C) was estimated using the carbon:chl a ratio of 42.7 originating from Disko bay, West Greenland waters during a similar successional stage of the phytoplankton community (JuulPedersen et al. 2006). Primary production was measured in situ applying the ${ }^{14} \mathrm{C}$ incubation technique (Steeman-Nielsen 1952). Triplicate samples from 5, 10, 20, 30 and $40 \mathrm{~m}$ were incubated in 2 clear and 1 dark glass bottles (120 ml) containing $200 \mu \mathrm{H} \mathrm{H}^{14} \mathrm{CO}_{3}{ }^{-}$for $2 \mathrm{~h}$ during mid-day. After incubation, the bottles were fixed with $100 \mu \mathrm{l} 5 \% \mathrm{ZnCl}_{2}$ and the entire content of each bottle was filtered onto GF/C filters and stored frozen in a vial. Before analysis, $100 \mu \mathrm{l} 1 \mathrm{~N} \mathrm{HCl}$ were added to the vials. The vials were fumed for $24 \mathrm{~h}$, after which PerkinElmer Ultima Gold scintillation liquid was added and the samples were counted on a PerkinElmer TriCarb 2800 TR liquid scintillation analyser. The gross primary production was calculated adding the actual dissolved inorganic carbon (DIC) values measured on a $\mathrm{CM} 5012 \mathrm{CO}_{2}$ coulometer as described by Rysgaard \& Glud (2004). Primary production was adjusted for irradiance using irradiance values for the sampling period provided by Asiaq (Greenland Survey), and integrated to $45 \mathrm{~m}$ depth.

Protozooplankton. Abundance, size and overall taxonomic composition of protozooplankton were determined at 3 depths; 10, 30 and $50 \mathrm{~m}$. At each depth, a $500 \mathrm{ml}$ water sample was fixed in acidic Lugol's solu- tion (final concentration 1\%). The samples were kept dark and cool until processing. A subsample $(50 \mathrm{ml})$ was allowed to settle for $24 \mathrm{~h}$ before it was counted under an inverted microscope. Ciliates and heterotrophic dinoflagellates were categorised by functional group, and cell lengths and widths were measured. The carbon content was calculated using the size measurements and carbon content factors according to Menden-Deuer \& Lessard (2000). Clearance of heterotrophic dinoflagellates and ciliates was calculated assuming maximum clearance according to the equations in Hansen et al. (1997) for ciliates:

$$
\log \left(C_{\max }\right)=1.491-0.23 \log \left(P_{\mathrm{vol}}\right)
$$

and for heterotrophic dinoflagellates:

$$
\log \left(C_{\max }\right)=0.851-0.23 \log \left(P_{\mathrm{vol}}\right)
$$

where $C_{\max }\left(10^{5} \mathrm{~h}^{-1}\right)$ (Fenchel 1982) is maximum specific clearance and $P_{\text {vol }}\left(\mu \mathrm{m}^{3}\right)$ is body volume. The clearance was converted to in situ temperatures by the application of a $Q_{10}$ of 2.8 (Hansen et al. 1997). Grazing was calculated from the clearance and the in situ chl a $\mathrm{C}$ for heterotrophic dinoflagellates and chl $a \mathrm{C}<11 \mu \mathrm{m}$ for ciliates. Growth was estimated using an average gross growth efficiency of 0.33 (Hansen et al. 1997).

Mesozooplankton. Samples of large mesozooplankton were collected by vertical hauls with a MultiNet (Hydrobios) equipped with five $300 \mu \mathrm{m}$ nets. The samples were collected at 5 depth intervals: $0-50,50-100$, 
$100-150,150-200$ and $200-270 \mathrm{~m}$. At stations with depths $<270 \mathrm{~m}$, samples were collected with a $200 \mu \mathrm{m}$ WP-2 net instead. Furthermore, samples of the smallsized mesozooplankton were collected in the upper $100 \mathrm{~m}$, using a $45 \mu \mathrm{m}$ WP-2 net. The mesozooplankton was fixed in buffered formaldehyde ( $4 \%$ final concentration), and identified to either species or genus and developmental stage. The prosome lengths of a minimum of 10 ind. in each copepod stage and the body lengths of a minimum of 20 nauplii were measured. Identifications and length measurements of mesozooplankton were made at the Arctic Agency, Poland. The carbon content of copepods was calculated using the length-weight regression given in the literature (Microsetella spp. provided by Satapoomin 1999; Paraeucheta norvegica by K. Tönnesson unpubl.; values for the remaining groups were summarised by Thor et al. 2005).

The egg production rate (EPR) and faecal pellet production (FPP) of Calanus finmarchicus and Metridia longa were measured. Healthy and active fertilised females of C. finmarchicus and M. longa were collected by vertical hauls from 100 to $0 \mathrm{~m}$ using a $200 \mu \mathrm{m}$ WP-2 net equipped with a large non-filtering cod end. The females were immediately placed in a $525 \mathrm{ml}$ polycarbonate bottle containing $50 \mu \mathrm{m}$ prescreened surface seawater. At each station, individual females were incubated in replicates of 8 to 20 bottles and incubated in a thermo box with flow-through surface water at in situ temperature. After $24 \mathrm{~h}$, eggs and faecal pellets (FP) were counted. Length and width of FP, the copepod prosome length and egg width were measured. Egg volumes were converted to carbon using a conver-

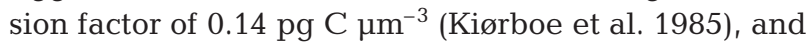
FP volumes were converted to carbon using a factor of

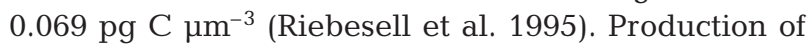
the copepod community (secondary production) was estimated using the total biomass of the large and small mesh nets multiplied by specific EPR measured for C. finmarchicus, assuming that specific EPR was equal to somatic growth of juveniles and other species (Berggreen et al. 1988). Grazing impact was not directly measured but was estimated from the EPR and FPP, assuming a gross growth efficiency of $33 \%$ (Hansen et al. 1997).

Sedimentation traps. Vertical flux was measured using 2 sediment traps, each equipped with paired cylinders ( $\varnothing 80 \mathrm{~mm} \times 450 \mathrm{~mm}, \mathrm{KC}$ Denmark). The traps were filled with GF/C filtered bottom water and deployed for 2 to $4 \mathrm{~h}$ at $60 \mathrm{~m}$ depth. After incubation, the entire contents of 2 traps were filtered onto GF/C filters. One filter was analysed for $\mathrm{chl} a$, and 1 filter was analysed for particulate organic carbon (POC). For POC analysis, a subsample of the filter was moistened with $1 \mathrm{M}$ sulphurous acid $\left(\mathrm{H}_{2} \mathrm{SO}_{3}\right)$, dried for $24 \mathrm{~h}$ at $60^{\circ} \mathrm{C}$ prior to analysis on an elemental analyser (SerCon ANCA GSL) in line with a mass spectrometer (SerCon Hydra 20-20). The molar C/N ratio was calculated as POC/particulate nitrogen (PN). One trap was stored cold and dark for $24 \mathrm{~h}$ before the settled particles were gently decanted and fixed in acidic Lugol's solution (final concentration 1\%). The numbers of intact and fragmented FP were counted under an inverted light microscope, and the sizes of 30 randomly intact or fragmented FP per station were measured. The volume was estimated using the equation of a cylinder and converted to biomass as in the copepod FPP experiments.

\section{RESULTS}

\section{Physical environment, nutrients and chlorophyll distribution}

The shallow Fyllas Banke with depths of approximately $40 \mathrm{~m}$ functions as a barrier separating the Godthåbsfjord from the offshore regions (Fig. 1). The offshore region outside Fyllas Banke is dominated by the West Greenland Current flowing northward along the West Greenland shelf (Buch 1990), while the fjord is strongly impacted by melt water from the surrounding area and the Greenland Ice Sheet.

The north-flowing currents contain highly saline water with maximum salinity, temperature and density at a plume below $300 \mathrm{~m}$ (Fig. 2). These water masses follow the bathymetry, as a side branch of this highly saline water can be seen on the inside of the bank close to the fjord inlet (Fig. 2). At Fyllas Banke (Stns FB2 and FB2.5) and at the inlet of the fjord (Stns GF2 and GF3) vertical mixing takes place because of the strong tidal forces. The fjord inlet is a turbulent area, as all water transport into and out of the fjord must pass the narrow inlet. At the central and inner parts of the fjord, a low-saline water plume in the upper parts of the water column is separated from the deeper water masses by a pycnocline (Figs. 2C \& 3). Despite the fact that the low-saline water originates from melting ice and snow, the low-saline water is warmer than the fjord water below due to atmospheric heating of the surface layer (Fig. 2B). At Stn GF13 close to the ice sheet, a plume of cold water $\left(<-0.5^{\circ} \mathrm{C}\right)$ is situated at $13 \mathrm{~m}$ water depth (Fig. 2B). In the deeper waters of the inner parts of the fjord, water of high salinity, temperature and density is observed, originating from occasional exchange with deeper water outside the fjord (Fig. 2).

The nutrient distribution followed the water column structure with low concentrations above the pycnocline (Fig. 3). At Fyllas Banke, nutrients were depleted 

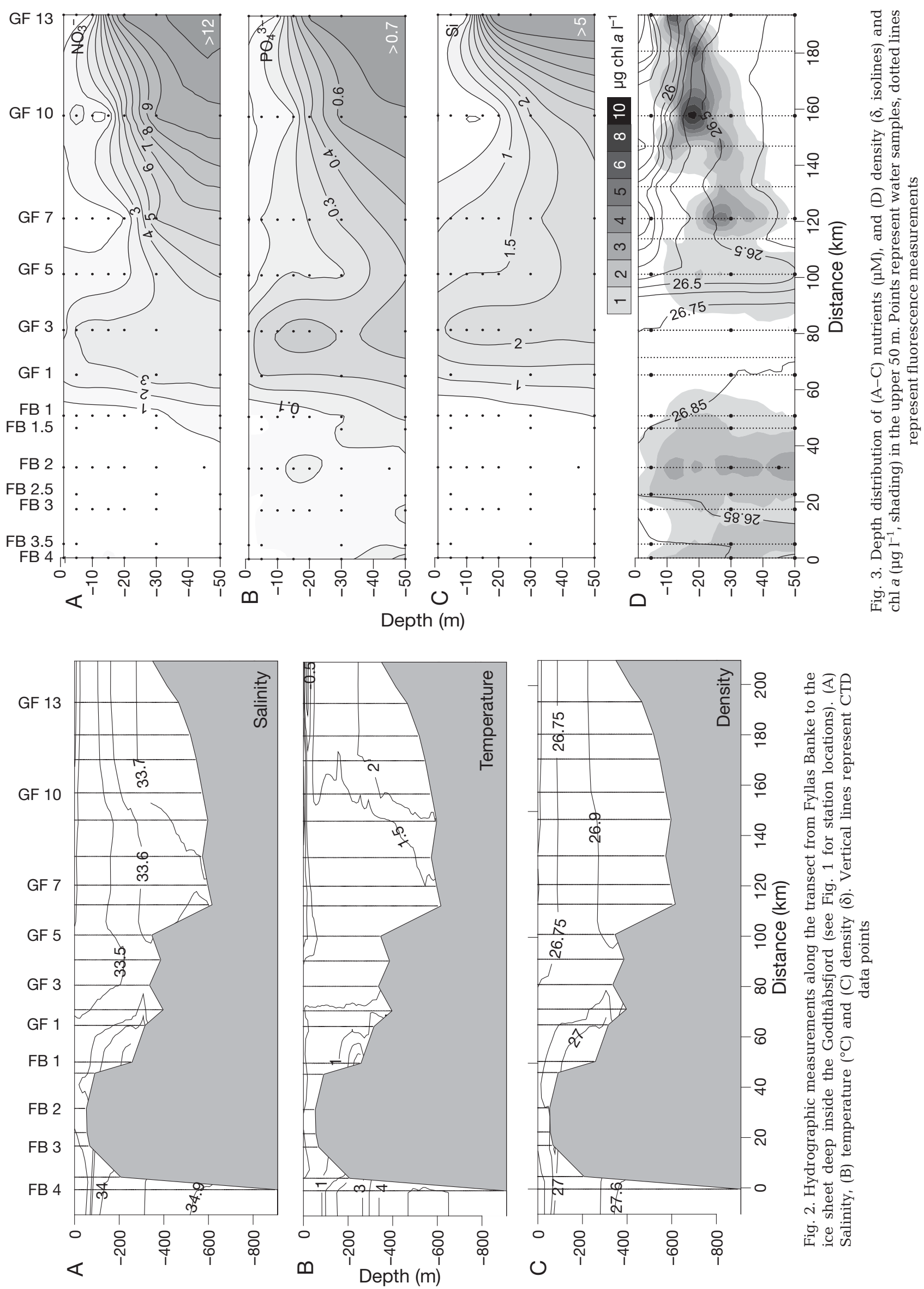
in the upper $50 \mathrm{~m}$, whereas high concentrations were found in the high-salinity waters below $300 \mathrm{~m}$ on the offshore parts of Fyllas Banke. Peak contents of all nutrients were observed at Stn FB4 at $600 \mathrm{~m}$ depth: $19.1 \mu \mathrm{M}$ nitrate, $1.0 \mu \mathrm{M}$ phosphate and $7.9 \mu \mathrm{M}$ silicate. A branch of this nutrient-rich water mass occurs in the deepest parts on the inside of the bank and at the innermost stations (data not shown). At the entrance to the fjord, nutrients were quite evenly distributed in the water column due to vertical mixing, while being depleted above the pycnocline at the fjord stations (Fig. 3).

Chl a was quite evenly distributed in the water column at Fyllas Banke, whereas low concentrations were observed at the fjord inlet due to vertical mixing (Fig. 3D). In the central and inner parts of the fjord, chl a distribution followed the pycnocline and the nutrient-rich water deep at the mouth of the fjord and gradually rose to the surface as it approached the innermost stations (Fig. 3). High chl a concentrations (11.8 $\mathrm{gg} \mathrm{l}^{-1}$ at Stn GF10) was observed in a subsurface layer at the pycnocline in these inner parts of the fjord.

\section{Plankton community structure}

The qualitative composition of the net phytoplankton $(>20 \mu \mathrm{m})$ varied along the section, with dominance of centric diatoms at the offshore stations and dominance of the colonial cells of the haptophytes Phaeocystis spp. at most stations on the bank and in the central parts of the fjord, while chain-forming diatoms (Thalassiosira spp.) dominated the station close to the Greenland Ice Sheet (Fig. 4A).

The protozooplankton community was dominated by ciliates and large $(>40 \mu \mathrm{m})$ athecate heterotrophic dinoflagellates (Gymnodinium spp. and Gyrodinium spp.) at all stations along the transect (Fig. 4B). Large $(>40 \mu \mathrm{m})$ ciliates constituted a greater part of the protozooplankton community on the bank, while small $(<40 \mu \mathrm{m})$ athecate dinoflagellates were more abundant at the fjord stations (Fig. 4B). Thecate dinoflagellates constituted only a small part of the heterotrophic biomass at all stations along the section $(<14 \%$ of total biomass).

The copepod community structure showed great variance along the transect (Fig. 5A,B), with dominance of the Calanus spp. in the offshore regions, Pseudocalanus spp. in the central parts of the fjord and Metridia longa and Microsetella spp. in the inner parts of the fjord.

In the offshore region, Calanus spp. constituted $>90 \%$ of the total biomass of both the MultiNet and WP-2 net $(200$ and $300 \mu \mathrm{m})$ samples (Fig. 5A). At the stations located on the slopes of the bank, larger cope-
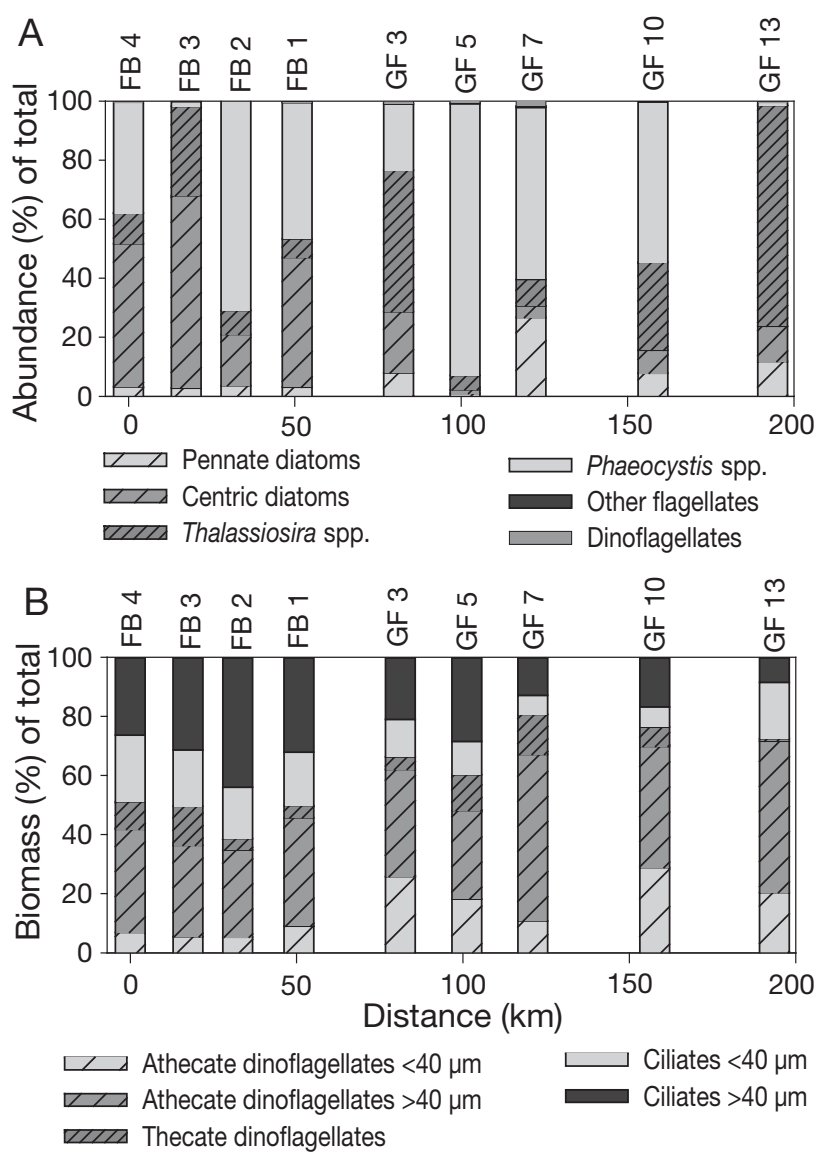

Fig. 4. (A) Net phytoplankton community composition ( $>20 \mu \mathrm{m})$, in \% of abundance. (B) Community composition of heterotrophic protozooplankton, in \% of total biomass. See Fig. 1 for station locations

podite stages of C. finmarchicus and C. hyperboreus were dominant, whereas nauplii and the copepodite stage CI of Calanus spp. dominated the assemblage in the central parts of the bank. Also in the $45 \mu \mathrm{m}$ net samples, Calanus spp. were the dominant group in the offshore region (Fig. 5B), although Pseudocalanus spp. constituted a considerable part of the total biomass (Fig. 5B). For a section from the open water to the ice sheet, along the fjord, Calanus spp. became gradually less abundant (Fig. 5A,B). Pseudocalanus spp. dominated the community in the central parts of the fjord, whereas Metridia longa constituted a considerable part at the station close to the ice sheet (Stn GF 13). In the $45 \mu \mathrm{m}$ net samples, Microsetella spp. made up a considerable part of the total biomass and became increasingly dominant towards the ice sheet (Fig. 5B).

\section{Plankton community biomasses}

At the offshore stations and the central parts of the bank, chl a was mainly present in the size fraction 


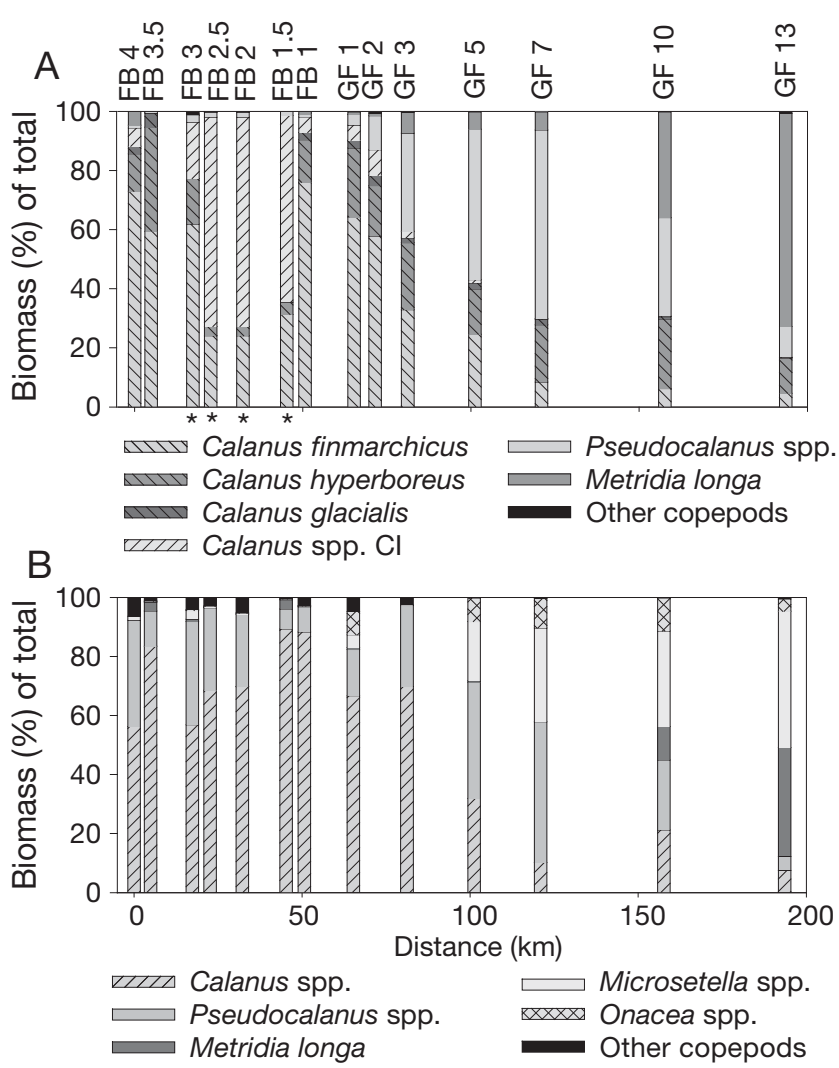

Fig. 5. Community composition of copepods, in \% of total biomass in (A) $300 \mu \mathrm{m}$ MultiNet and $200 \mu \mathrm{m}$ WP-2 net (*) and (B) $45 \mu \mathrm{m}$ WP-2 net. See Fig. 1 for station locations

$>40 \mu \mathrm{m}$ (Figs. 3D \& 6A). However, the plankton communities of the central parts of the fjord turned out to be mainly $<40 \mu \mathrm{m}$ (Figs. 3D \& 6). The highest chl a concentration was observed at Stn GF10, where the measured chl a for the size fractions $<11 \mu \mathrm{m}, 11-40 \mu \mathrm{m}$ and $>40 \mu \mathrm{m}$ was $4.8,4.6$ and $2.4 \mu \mathrm{g} \mathrm{l}^{-1}$, respectively. At the innermost station, chl a was mainly in the size fraction $>40 \mu \mathrm{m}$ (Fig. 6A) due to the dominance of chainforming diatoms.

The integrated biomass ( $\mathrm{chl}$ a converted to biomass: chl a C) of the primary producers in the upper $50 \mathrm{~m}$ was highest in the central parts of the bank (4857 mg C $\mathrm{m}^{-2}$ ), while it declined steeply at the entrance to the fjord (833 $\mathrm{mg} \mathrm{C} \mathrm{m}^{-2}$, Fig. 7A). In the fjord, integrated biomass varied from 1672 to $4253 \mathrm{mg} \mathrm{C} \mathrm{m}^{-2}$, with 2 distinct peaks in the central parts, while decreasing at the station closest to the ice sheet.

The standing stock of heterotrophic protozooplankton followed the same pattern as the primary producers (Fig. 7B). Biomasses were high offshore (817 to $1301 \mathrm{mg} \mathrm{C} \mathrm{m}^{-2}$ ) and declined to $497 \mathrm{mg} \mathrm{C} \mathrm{m}^{-2}$ at the entrance to the fjord and increasing to $1545 \mathrm{mg} \mathrm{C} \mathrm{m}^{-2}$ in the central parts of the fjord. Low biomasses were found at the station closest to the ice sheet $\left(559 \mathrm{mg} \mathrm{C} \mathrm{m}^{-2}\right.$ ).
The total biomass of the copepod community showed great variability along the transect, with 2 peaks in association with the fronts on the slopes of the bank and low biomasses on the bank itself and within the fjord (Fig. 8A,B). The 200 and $300 \mu \mathrm{m}$ mesh nets showed 2 peaks in biomass on either side of the bank (9310 and $4671 \mathrm{mg} \mathrm{C} \mathrm{m}^{-2}$ ). Biomasses were more than an order of magnitude lower (ca. $500 \mathrm{mg} \mathrm{C} \mathrm{m}^{-2}$ ) in the central parts of the bank, at the entrance of the fjord and at the stations close to the ice sheet, while there was a small biomass peak in the central part of the fjord (1016 $\mathrm{mg} \mathrm{C} \mathrm{m}^{-2}$ ). The biomass sampled with the $45 \mu \mathrm{m}$ mesh net (0 to $100 \mathrm{~m}$ ) generally followed the same pattern as the larger mesh nets (Fig. 8B). Biomass peaked on either side of the bank (1330 and $1655 \mathrm{mg} \mathrm{C}$ $\mathrm{m}^{-2}$ ) but was low at all other stations. It is notable that the biomass of the $45 \mu \mathrm{m}$ mesh net exceeded $100 \%$ of the biomass sampled with the $300 \mu \mathrm{m}$ net at the entrance of the fjord.

Vertical distribution of the copepod biomass (data from 200 and $300 \mu \mathrm{m}$ mesh nets) showed explicit division of the habitat of the 3 dominating species (Calanus finmarchicus, Pseudocalanus spp. and Metridia longa; Fig. 9). Maximum biomass of $C$. finmarchicus was found in the 50 to $100 \mathrm{~m}$ sample on either side of the bank (81 and $8.7 \mathrm{mg} \mathrm{C} \mathrm{m}^{-3}$, respectively), but species were well represented ( $>1 \mathrm{mg} \mathrm{C} \mathrm{m}^{-3}$ ) in the water column down to $200 \mathrm{~m}$ at the offshore stations and at the mouth of the fjord (Fig. 9A). Pseudocalanus spp., the dominating species in the central parts of the fjord, were also well represented $\left(>1 \mathrm{mg} \mathrm{C} \mathrm{m}^{-3}\right.$ ) down to $200 \mathrm{~m}$ depth but had a maximum abundance of $5.5 \mathrm{mg}$ $\mathrm{C} \mathrm{m}^{-3}$ in the upper $50 \mathrm{~m}$ (Fig. 9B). Close to the ice sheet, the dominant species $M$. longa was well represented in the water column at 50 to $150 \mathrm{~m}$ depth, with a maximum abundance of $2.6 \mathrm{mg} \mathrm{C} \mathrm{m}^{-3}$ at 100 to $150 \mathrm{~m}$ (Fig. 9C). The biomass of $M$. longa was negatively correlated to fluorescence $(\mathrm{r}=-0.74, \mathrm{n}=55, \mathrm{p}<0.01)$ and positively correlated with temperature and depth $(\mathrm{r}=$ 0.52, $\mathrm{n}=55, \mathrm{p}<0.01$ and $\mathrm{r}=0.53, \mathrm{n}=55, \mathrm{p}<0.01$, respectively).

\section{Plankton community production and vertical flux}

In the outer parts of Fyllas Banke, primary production exceeded $1200 \mathrm{mg} \mathrm{C} \mathrm{m}^{-2} \mathrm{~d}^{-1}$, while it decreased in the central parts of the bank (Stn FB2; $466 \mathrm{mg} \mathrm{C} \mathrm{m}^{-2}$ $\mathrm{d}^{-1}$; Fig. 10A). Along the fjord, primary production increased towards the stations close to the ice sheet where very high primary production rates were found (1739 $\mathrm{mg} \mathrm{C} \mathrm{m}^{-2} \mathrm{~d}^{-1}$ ).

Secondary production of the protozooplankton also varied considerably along the transect (Fig. 10 B). Protozooplankton production in the offshore region was 

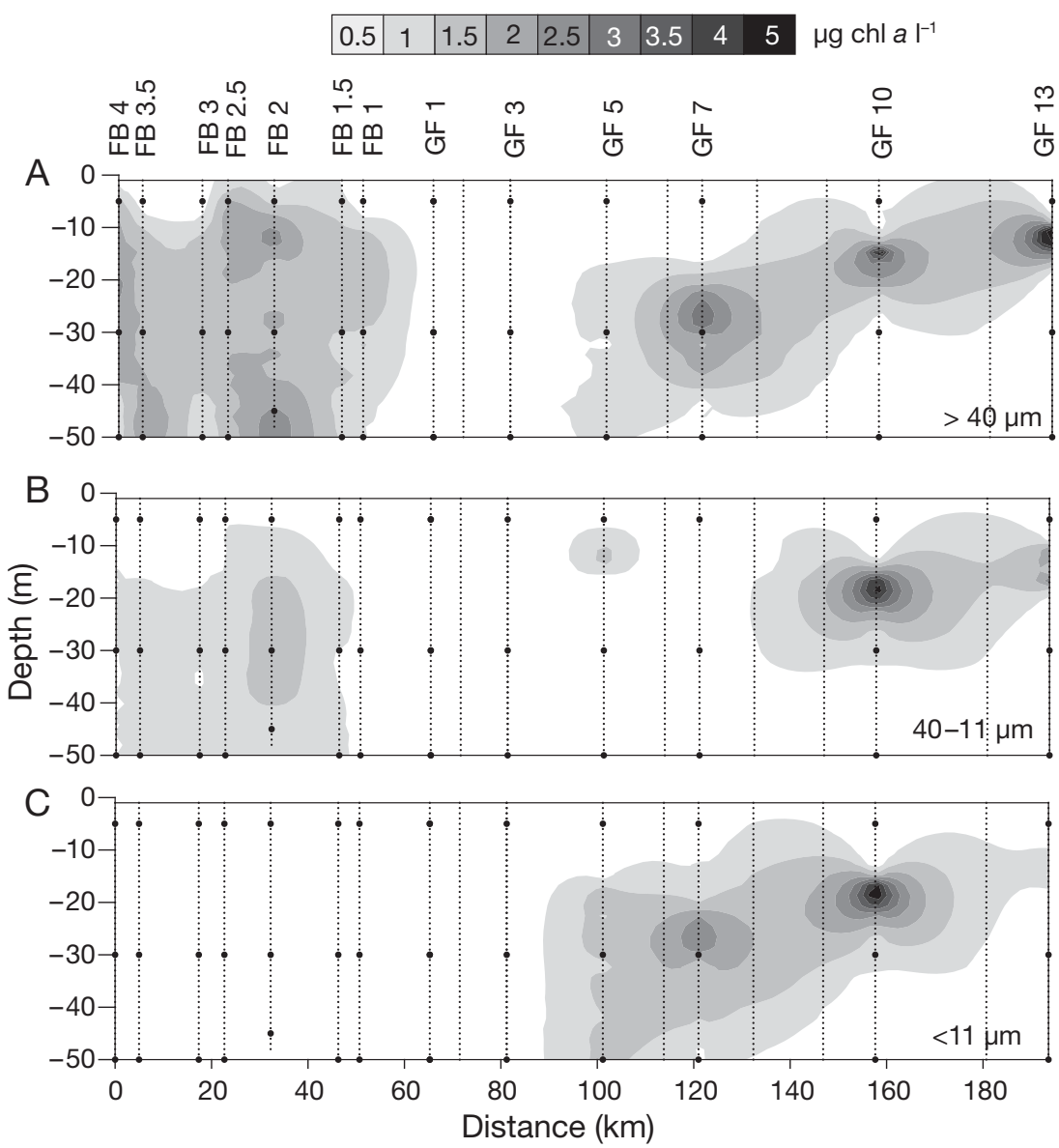

Fig. 6. Fractionated chl a $\left(\mu \mathrm{g} \mathrm{l}^{-1}\right)$ for cells (A) $>40 \mu \mathrm{m}$, (B) 11-40 $\mu \mathrm{m}$ and (C) $<11 \mu \mathrm{m}$. Points represent water samples, dotted lines represent fluorescence measurements. See Fig. 1 for station locations estimated to between 33 and $66 \mathrm{mg} \mathrm{C} \mathrm{m}^{-2}$ $\mathrm{d}^{-1}$, with the lowest production at the $\stackrel{m}{-}$ entrance to the fjord, while production increased inside the fjord (Fig. 10B).

The EPR of Calanus finmarchicus was high close to and on Fyllas Banke (19 to 27 eggs female ${ }^{-1} \mathrm{~d}^{-1}$, Fig. 11A) and, at the same stations, high rates of FPP were measured (33 to 38 FP female ${ }^{-1} \mathrm{~d}^{-1}$ ). The EPR and FPP declined at the entrance to the fjord, while it increased in the central parts of the fjord, but decreased at the station closest to the ice sheet. The EPR and FPP of Metridia longa were only measured at the innermost fjord stations. EPR was between 1.5 and 7.8 female $^{-1} \mathrm{~d}^{-1}$ and FPP between 4.5 and $7.8 \mathrm{fem}^{-1} \mathrm{~d}^{-1}$ (Fig. 11A).

There was a significant correlation between specific egg production rate (SEP) and specific faecal pellet production (SPP; Table 1), with a median FP volume of $3.3 \times$ $10^{6} \mu \mathrm{m}^{3} \pm 0.08 \times 10^{6}, \mathrm{n}=593$. SPP was significantly correlated with total biomass of chl a (mg chl a m $\mathrm{m}^{-2}$ ) and in the 11 to $40 \mu \mathrm{m}$ size spectrum, whereas a significant correlation was not found for SEP (Table 1). Due to the significant correlation between SPP and chl $a$ in the 11 to $40 \mu \mathrm{m}$ size spectrum, which is assumed to be the major food source for Calanus finmarchicus, the grazing rate of the copepod community was based on the SPP of $C$. finmarchicus.

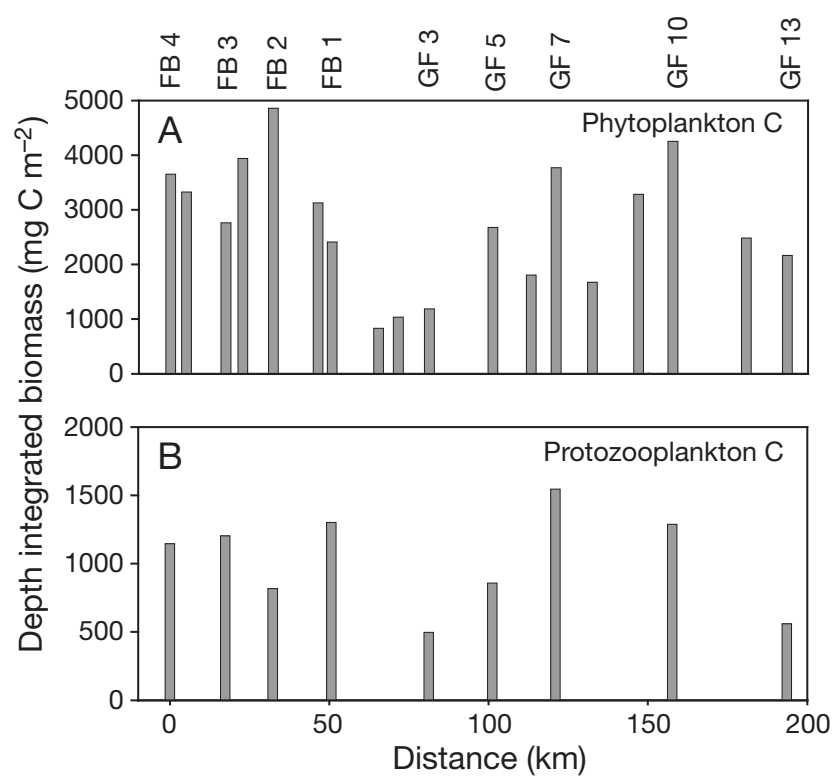

Fig. 7. Depth integrated biomass $\left(0-50 \mathrm{~m}, \mathrm{mg} \mathrm{C} \mathrm{m}{ }^{-2}\right)$ of (A) phytoplankton and (B) heterotrophic protozooplankton. See Fig. 1 for station locations

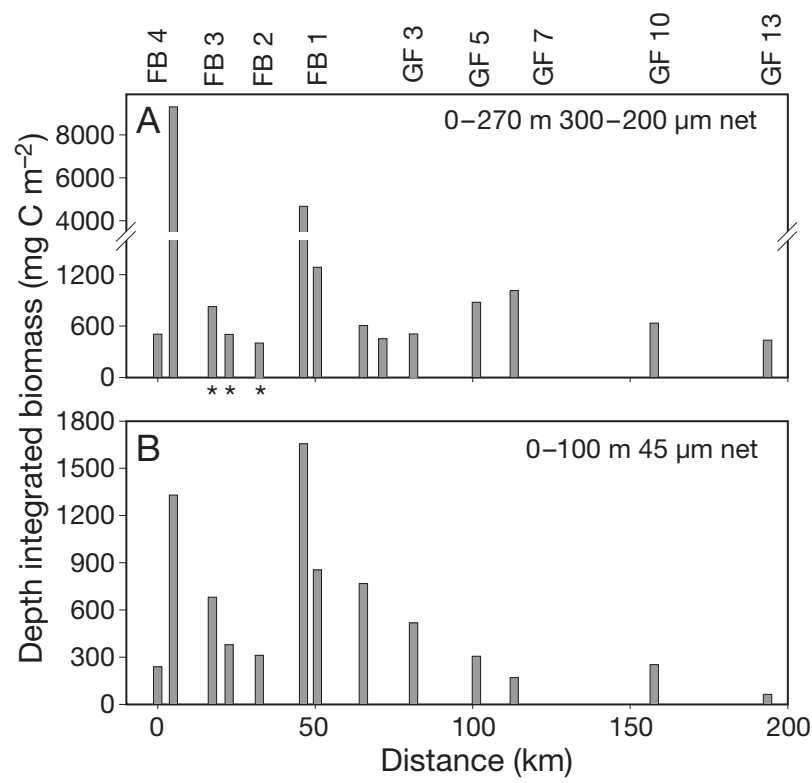

Fig. 8. Depth integrated biomass of copepods $\left(\mathrm{mg} \mathrm{C} \mathrm{m}^{-2}\right)$ sampled with (A) $300 \mu \mathrm{m}$ MultiNet and $200 \mu \mathrm{m}$ WP-2 net (*) and (B) $45 \mu \mathrm{m}$ WP-2 net. See Fig. 1 for station locations 

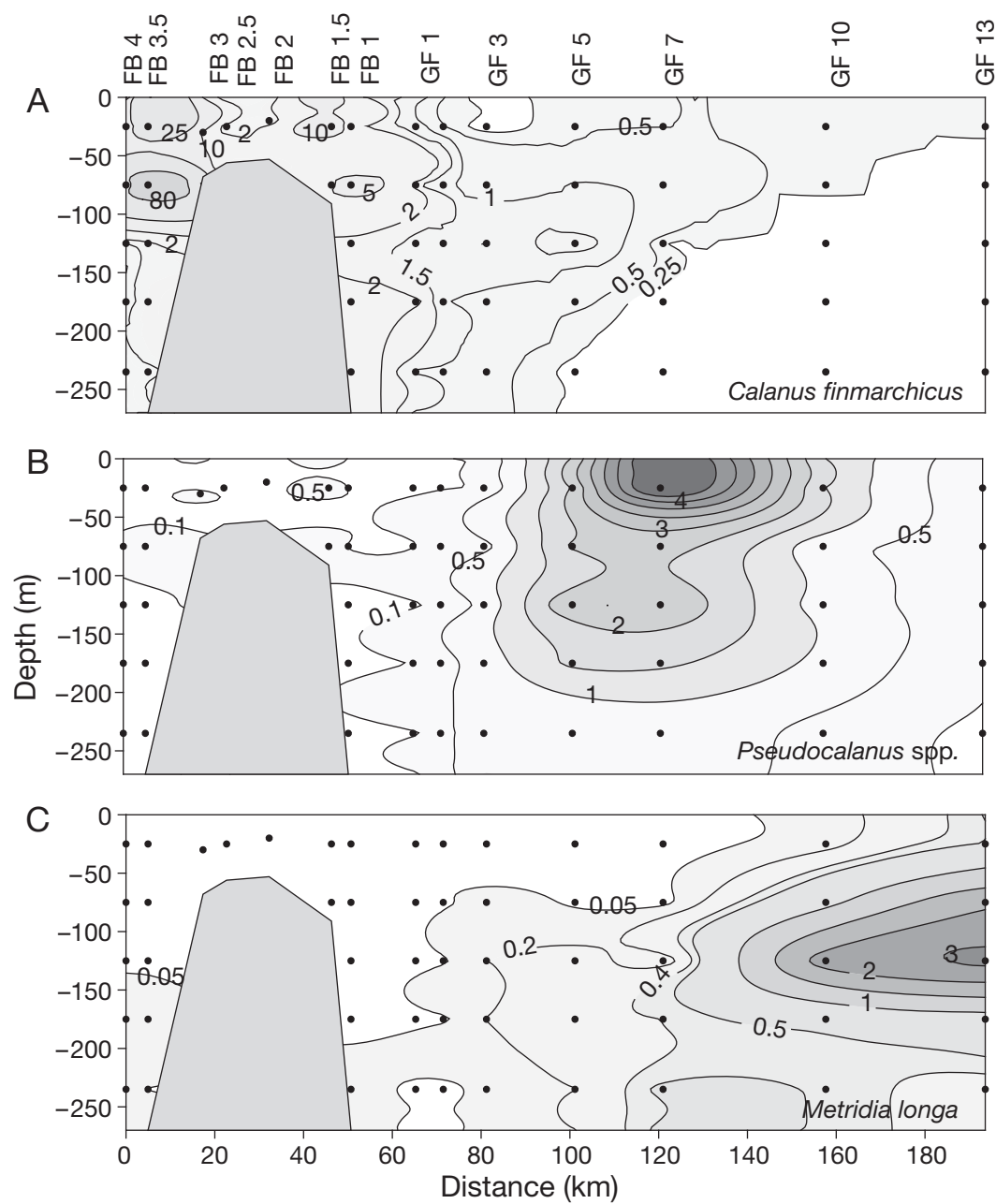

Fig. 9. (A) Calanus finmarchicus, (B) Pseudocalanus spp. and (C) Metridia longa. Distribution of copepod biomass $\left(\mathrm{mg} \mathrm{C} \mathrm{m}^{-3}\right)$ along the transect sampled with the $300 \mu \mathrm{m}$ MultiNet and $200 \mu \mathrm{m}$ WP-2 net. Dots represent sample intervals. See Fig. 1 for sampling locations
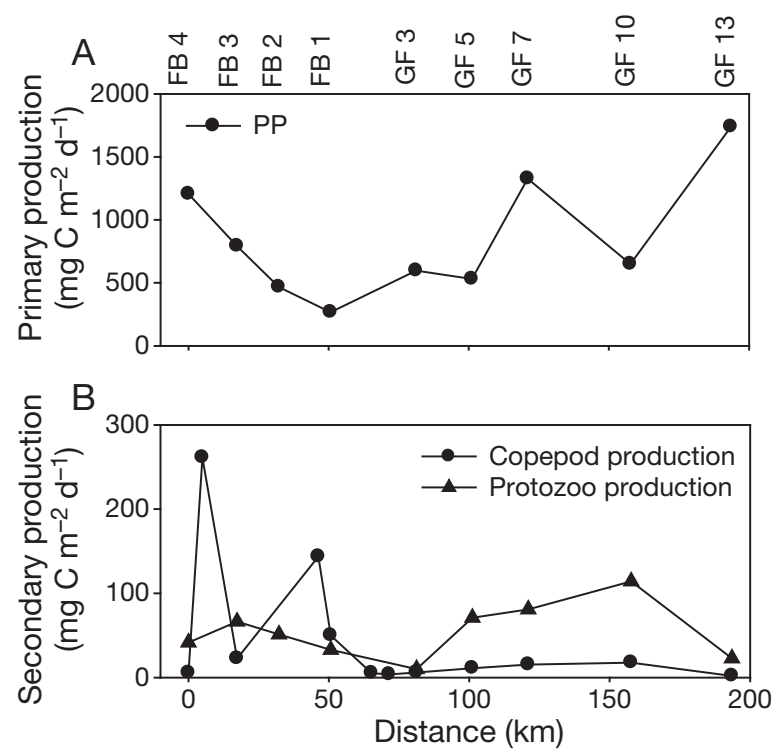

Copepod production closely followed the distribution of copepod biomass, with 2 very high peaks in production in the offshore region, whereas the production was notably lower at the remaining stations (Fig. 10B). On either side of the bank, very high copepod productions were observed (299 and $194 \mathrm{mg} \mathrm{C} \mathrm{m}^{-2}$ $\mathrm{d}^{-1}$ ), while production at the remaining offshore stations varied between 8 and $41 \mathrm{mg} \mathrm{C} \mathrm{m}^{-2} \mathrm{~d}^{-1}$. In the fjord, production was generally low, being highest at the central station (up to $25 \mathrm{mg} \mathrm{C} \mathrm{m}^{-2} \mathrm{~d}^{-1}$ ) and lowest close to the ice sheet $(2 \mathrm{mg} \mathrm{C}$ $\mathrm{m}^{-2} \mathrm{~d}^{-1}$ ). There was no significant correlation between secondary production and the biomass of chl $a(r=0.15, n=10)$. The general pattern of EPR and estimated secondary copepod production is corroborated by the abundance of copepod eggs and nauplii in the $45 \mu \mathrm{m}$ mesh net (Fig. 11B).

Vertical fluxes from the photic zone were high in the offshore region, and lower at the fjord stations (Fig. 12). Measured POC, entering the trap in the outer parts of Fyllas Banke, was $>1594 \mathrm{mg} \mathrm{m}^{-2}$ $\mathrm{d}^{-1}$ and of that, $>721$ was due to phytoplankton carbon, according to the measured chl a. In the central parts of the bank, a high amount of chl a (1261 mg C $\mathrm{m}^{-2} \mathrm{~d}^{-1}$ ) was measured in the trap. In the fjord, the vertical fluxes were lower between 658 and $1165 \mathrm{mg}$ POC m $\mathrm{m}^{-2} \mathrm{~d}^{-1}$, and between 140 and $766 \mathrm{mg} \mathrm{C} \mathrm{m}^{-2} \mathrm{~d}^{-1}$ was due to chl a (Fig. 12). The flux of FPC shows some similarities with the FP community production, with the highest flux at station GF10 in the inner fjord (Fig. 12).

\section{DISCUSSION}

The present study showed a steep gradient in physical, chemical and biological conditions from the offshore regions along the Godthåbsfjord to the Greenland Ice Sheet. This gradient was strongly reflected in the plankton community structure. The strong physical/ chemical gradient might induce these large changes in the plankton community composition. The geographi-

Fig. 10. (A) Primary production (PP) in the upper $50 \mathrm{~m}$ (mg C $\left.\mathrm{m}^{-2} \mathrm{~d}^{-1}\right)$, and (B) secondary production $\left(\mathrm{mg} \mathrm{C} \mathrm{m}^{-2} \mathrm{~d}^{-1}\right)$ of copepods $(0-270 \mathrm{~m})$ and protozooplankton (protozoo) $(0-50 \mathrm{~m})$. See Fig. 1 for sampling locations 


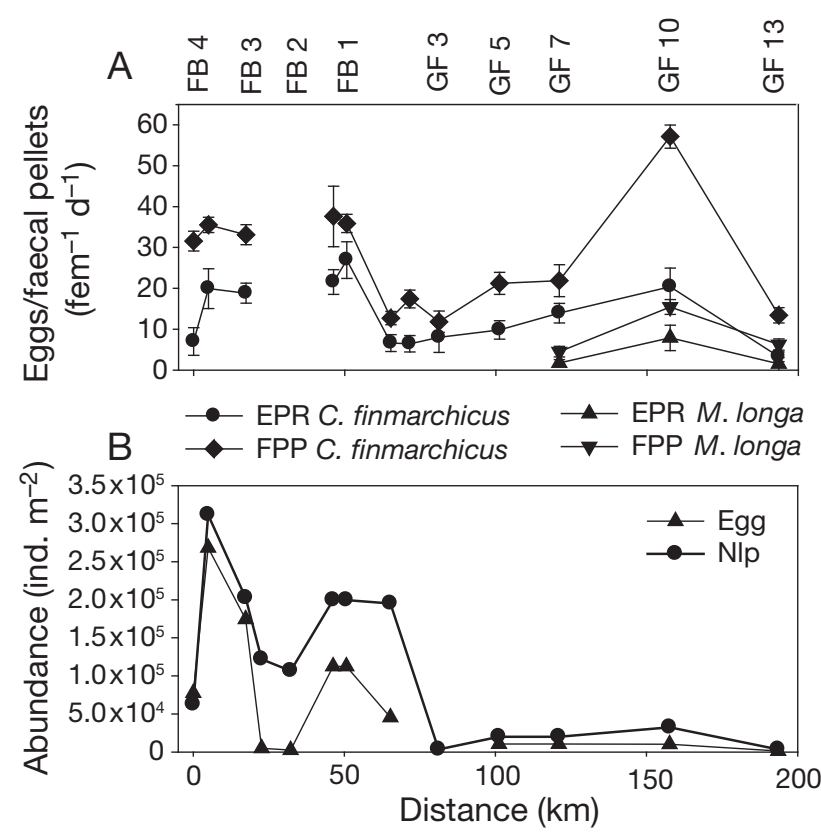

Fig. 11. Calanus finmarchicus and Metridia longa. Differences in (A) egg production rate (EPR) and faecal pellet production (FPP; female ${ }^{-1} \mathrm{~d}^{-1}$ ) and (B) abundance (ind. $\mathrm{m}^{-2}$ ) of copepod eggs (Egg) and nauplii (Nlp) sampled with the $45 \mu \mathrm{m}$ WP-2 net along the transect. See Fig. 1 for sampling locations

cal distribution of zooplankton has been confirmed by investigations at other times of the year (Rysgaard et al. 2008 and K. Arendt pers. obs.) and is furthermore in accordance with observations by Smidt (1979). Therefore, the differences in copepod community structure cannot be explained by differences in succession stage along the section.

The study showed a general shift in physical/chemical factors and water column structure at the entrance to the fjord (Figs. $2 \& 3$ ). Likewise, there is a general shift in the species composition (Figs. 4, 5, \& 9) and biomasses (Figs. $7 \&$ 8) of the plankton communities at the entrance to the fjord. Therefore, it is reasonable to split up the study area into 2 systems, viz. the offshore

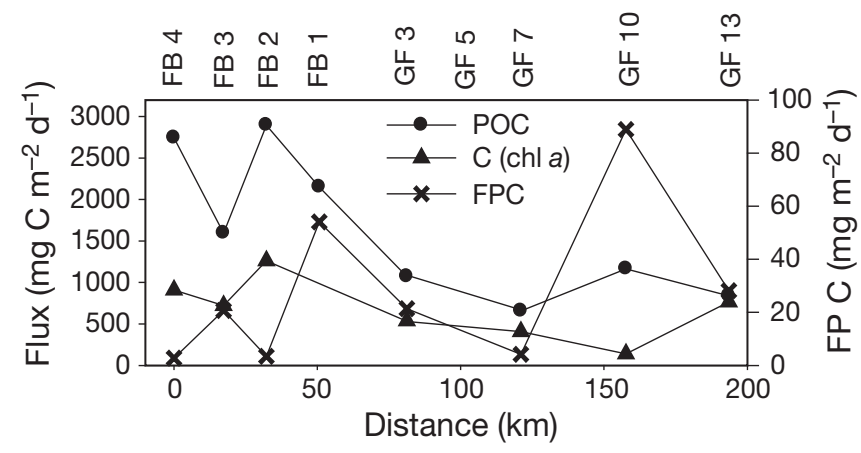

Fig. 12. Differences in flux of particulate organic carbon (POC), C (chl a) and faecal pellet (FP) $\mathrm{C}\left(\mathrm{mg} \mathrm{m}^{-2} \mathrm{~d}^{-1}\right)$ in the upper $60 \mathrm{~m}$. See Fig. 1 for sampling locations
Table 1. Correlation coefficients (r) in linear regression between specific egg production (SEP), specific pellet production (SPP), and chl a measurements $\left(\mathrm{mg} \mathrm{m}^{-2}\right)$. Significance of the correlation is given by an asterisk: ${ }^{*} \mathrm{p}<0.05,{ }^{* *} \mathrm{p}<0.01$

\begin{tabular}{|lcc|}
\hline & $\begin{array}{c}\text { SEP } \\
\mathrm{r}(\mathrm{n}=12)\end{array}$ & $\begin{array}{c}\text { SPP } \\
\mathrm{r}(\mathrm{n}=12)\end{array}$ \\
\hline SEP & - & $0.60^{*}$ \\
Chl $a$ total & 0.46 & $0.69^{*}$ \\
Chl $a<11 \mu \mathrm{m}$ & 0.00 & 0.15 \\
Chl $a$ 11 $-40 \mu \mathrm{m}$ & 0.47 & $0.92^{* *}$ \\
\hline
\end{tabular}

region and the fjord. An overview of the carbon budget for the upper $50 \mathrm{~m}$ in the 2 systems is shown in Fig. 13.

Mean biomass and production rate for the primary producers and the mean biomass and carbon turnover by the protozooplankton are roughly in the same range in the offshore region and the fjord system (Fig. 13). In contrast, the vertical flux was twice as high in the offshore region than in the fjord (Fig. 13), indicating a transport to the area as more material is lost than produced. Furthermore, there is a large difference in the copepod biomass and their carbon turnover in the offshore region and the fjord system (Fig. 13). Our data indicate that the differences in copepod community structure and biomass are determined by the hydrographic conditions. The offshore region is strongly influenced by the Atlantic inflow, resulting in dominance of the true Atlantic species Calanus finmarchicus, whereas the fjord was strongly influenced by glacial runoff and therefore had a unique species composition with much lower biomasses. Two high peaks of copepod biomass were observed in association with the fronts on both sides of Fyllas Banke. These copepods were productive, resulting in large numbers of Calanus spp. copepodites in the central parts of the bank. In the offshore region, copepods were able to turn over $213 \pm 80 \mathrm{mg} \mathrm{C} \mathrm{m}^{-2} \mathrm{~d}^{-1}$ (ca. $33 \%$ ) of the primary production, which exceeds the carbon turnover by protozooplankton of $144 \pm 22 \mathrm{mg} \mathrm{C} \mathrm{m}^{-2} \mathrm{~d}^{-1}$ (Fig. 13A).

In the fjord, copepod biomasses were remarkably low, which has been found to be the case most of the year (Rysgaard et al. 2008). The dominating copepod species were Pseudocalanus spp., Metridia longa and Microsetella spp. The low biomasses are due to the low abundance of Calanus spp., and the copepod community was able to turn over only $3 \%$ of the primary production (Fig. 13B). Grazing by protozooplankton is approximately the same as in the offshore region $\left(179 \pm 58 \mathrm{mg} \mathrm{C} \mathrm{m}^{-2} \mathrm{~d}^{-1}\right)$ and by far exceeds the copepod grazing (24 $\pm 13 \mathrm{mg} \mathrm{C} \mathrm{m}^{-2} \mathrm{~d}^{-1}$; Fig. 13B). Thus, protozooplankton is important for the carbon turnover of the primary production in the fjord, in accordance with other studies that have shown that protozooplankton are ubiquitous in arctic regions (Levinsen \& Nielsen 2002, Verity et al. 2002, Møller et al. 2006). 

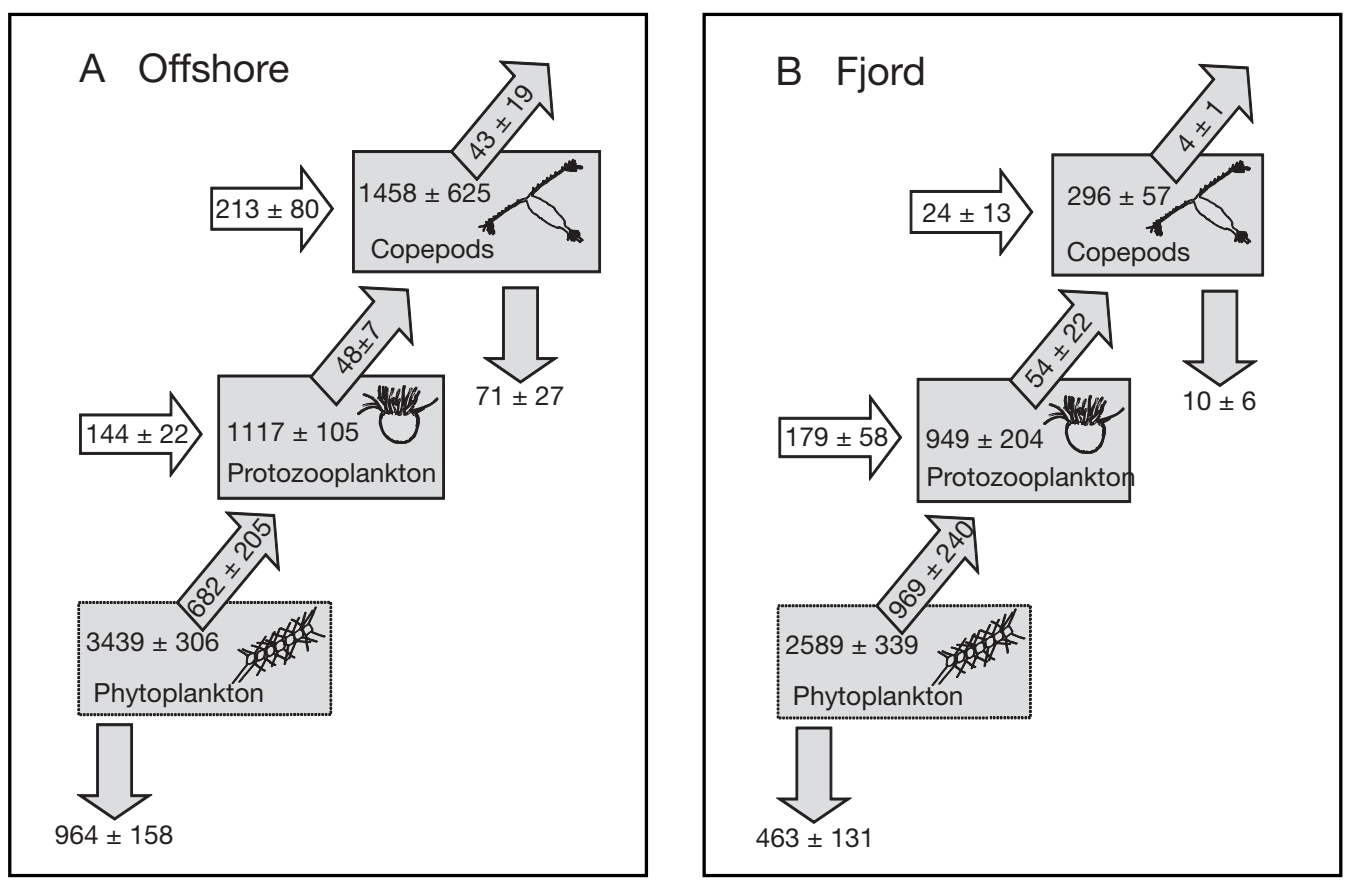

Fig. 13. Carbon flow budgets for the upper $50 \mathrm{~m}$ in (A) the offshore region and (B) the fjord as integrated mean \pm SE. Numbers in boxes show average biomass $\left(\mathrm{mg} \mathrm{C} \mathrm{m}^{-2}\right)$, numbers in arrows entering and leaving the boxes represent ingestion and production ( $\mathrm{mg} \mathrm{C} \mathrm{m} \mathrm{C}^{-2} \mathrm{~d}^{-1}$, and vertical arrows leaving the boxes represent vertical flux $\left(\mathrm{mg} \mathrm{chl} \mathrm{C} \mathrm{m}^{-2} \mathrm{~d}^{-1}\right)$

At Stn GF13, 3 glacial fronts that lie within a distance of $3 \mathrm{~km}$ (Fig. 1) strongly influence the plankton community. We suggest that these conditions determine the unique species composition of the copepod community. Primary production was high at this station due to nutrient-rich upwelling in front of the glacier (Fig. 3).

It should be taken into consideration that the production and grazing rates of the copepod community in the fjord were estimated on the basis of production rates of Calanus finmarchicus. The production rates of this species were probably not representative of the copepod species dominating the fjord stations, as the growth and fecundity rates of different species can vary significantly (Hirst \& Bunker 2003). Therefore, production was estimated according to Hirst \& Bunker (2003) (Table 2, all data) using in situ temperatures and chl $a$. The results of the 3 methods used to determine the production rate are shown in Table 2 . The estimated production rate falls remarkably close to the measured production on the basis of SEP and SPP in the offshore area. However, the estimated production rates were higher than the production measured on the basis of SEP and SPP in the fjord. The results indicate that the dominating copepods in the fjord (Pseudocalanus spp., Metridia longa and Microsetella sp.) have different life strategies than $C$. finmarchicus and that the measured production of this species probably underestimates the production of other species. The flux rates from the traps, which were deployed for only a short time, were extrapolated to daily rates, and it should be taken into consideration that dual migration and feeding rhythm of the grazers could have an influence on the dual flux.

Table 2. Production $\left(\mathrm{mg} \mathrm{C} \mathrm{m}^{-2} \mathrm{~d}^{-1}\right)$ of the copepod community in the upper $50 \mathrm{~m}$, measured as specific egg production (SEP) and specific pellet production (SPP) assuming a gross growth efficiency of $33 \%$ (Hansen et al. 1997) and estimated according to Hirst \& Bunker (2003)

\begin{tabular}{|lccc|}
\hline Station & $\begin{array}{c}\text { Production } \\
\text { based on SEP }\end{array}$ & $\begin{array}{c}\text { Production } \\
\text { based on SPP }\end{array}$ & $\begin{array}{c}\text { Estimated } \\
\text { production }\end{array}$ \\
\hline Offshore & & & \\
FB4 & 2.1 & 12.0 & 13.8 \\
FB3.5 & 56.4 & 130.8 & 70.2 \\
FB3 & 31.7 & 64.6 & 43.7 \\
FB2.5 & 20.1 & 33.3 & 35.2 \\
FB2 & 26.8 & 16.2 & 33.0 \\
FB1.5 & 152.7 & 202.0 & 130.0 \\
FB1 & 23.7 & 26.9 & 26.1 \\
Average \pm SE & $43.3 \pm 19.3$ & $70.9 \pm 26.5$ & $50.3 \pm 14.8$ \\
Fjord & & & \\
GF1 & 4.3 & 4.6 & 14.6 \\
GF2 & 0.4 & 0.8 & 3.0 \\
GF3 & 3.3 & 3.9 & 11.4 \\
GF5 & 3.8 & 4.9 & 17.3 \\
GF7 & 7.4 & 6.2 & 27.8 \\
GF10 & 8.0 & 33.6 & 20.0 \\
GF13 & 0.5 & 1.4 & 8.1 \\
Average \pm SE & $4.6 \pm 1.4$ & $10.0 \pm 6.0$ & $14.6 \pm 3.1$ \\
\hline
\end{tabular}


The overall species composition and biomass distribution are in accordance with other high-latitude fjords (Hop et al. 2002). It has been suggested that zooplankton in glacier-influenced fjords suffers direct mortality from the glacial outflow (Hop et al. 2002). High concentration of silt could presumably be fatal for the suspension-feeding copepods (e.g. Calanus spp.), while the omnivorous feeding strategy of Metridia longa would probably remain unaffected. Differences in numerous physical/chemical factors create microhabitats that affect the distribution of copepods due to their species-specific responses to environmental factors.

\section{Potential climate change effects on plankton community structure}

Rapid changes in the environmental conditions have occurred over the last decade in both offshore waters and fjord regions. The fjord must receive increased amounts of melt water as the Greenland Ice Sheet is losing mass (Velicogna \& Wahr 2006), including the glaciers in the inner parts of Godthåbsfjorden (Rignot \& Kanagaratnam 2006). Models have shown that increased runoff from land would not change the thickness of the mixed layer above the pycnocline in the fjord, although it is expected to intensify the estuarine circulation and bring more nutrient-rich water from the shelf into the fjord (Bendtsen et al. 2007). Enhanced estuarine circulation would enhance new production and could expand the area with high primary production, which at present is located in the inner part of the fjord close to the ice sheet. An expanded area with very high primary productivity would probably lead to a significant rise in the vertical flux, which would fuel the benthic community in an extended portion of the fjord.

In the offshore region, temperature has increased both in coastal West Greenland waters (Holland et al. 2008) and in the entire Baffin Bay (Zweng \& Münchow 2006). The increase in temperature could lead to decreasing peak phytoplankton biomass, decreasing mean cell size and a shift towards reduced dominance of diatoms (Sommer \& Lengfellner 2008). In the present study, a significant relationship was found between SPP and standing stock of chl $a$ in the 11 to $40 \mu \mathrm{m}$ size spectrum, indicating that Calanus finmarchicus finds its prey items mainly in this size spectrum, which is in accordance with other studies showing that this is the optimum cell size range for particles taken by Calanus (Frost 1972, Berggreen et al. 1988, Levinsen et al. 2000) and that the species is primarily herbivorous (Marshall \& Orr 1955, Meyer-Harms et al. 1999). The SPP was correlated with the SEP, indicating close coupling between ingestion and secondary pro- duction. A shift towards smaller cell size of primary producers would enhance the role played by protozooplankton in the carbon turnover and thus lead to losses in energy transfer to copepods (Sommer \& Lengfellner 2008). This situation seems to be present in the central fjord region where small cells represent a considerable part of the phytoplankton assemblage (Fig. 6), and protozooplankton accounts for $33 \%$ of the turnover of the primary production (Fig. 13B). A temperature rise would furthermore accelerate the physiological rates of both autotrophic and heterotrophic organisms (Hirst $\&$ Bunker 2003), and more nutrients would be recycled in the pelagic due to an increased proportion of the carbon being assimilated by the microbial community (Rivkin \& Legendre 2001). Changes in both runoff from land and Atlantic inflow are expected to occur in the future (Kattsov \& Källén 2005), and we have shown that the changes might have a strong influence on carbon cycling in West Greenlandic waters.

The strength and heat capacity of Atlantic inflow together with the runoff from the ice sheet determine the physical gradients and thereby the geographical distribution of the plankton community structure, which is shown clearly in the present study. However, the exact mechanisms determining the copepod community distribution and their specific adaptations to physical/chemical gradients are still unknown. Further studies of species-specific adaptation would provide key knowledge to determine the geographical distribution of the plankton communities in the future.

Acknowledgements. This project was funded by the Danish Energy Agency as part of the climate support programme to the Arctic. Financial support was received from the Greenland Institute of Natural Resources, the Aage V. Jensen Charity Foundation, a grant from the Commission for Scientific Research in Greenland (KVUG) to K.E.A. and a grant from the Danish Natural Sciences Research Council to T.G.N. Asiaq (Greenland Survey) is acknowledged for providing irradiance data. We thank K. Nielsen and the crew on RV 'Adolf Jensen' for field assistance. In particular, we thank M. Frederiksen for leading the cruise and A. Haxen for linguistic corrections.

\section{LITERATURE CITED}

Aure J, Strand Ø, Erga S, Strohmeier T (2007) Primary production enhancement by artificial upwelling in a western Norwegian fjord. Mar Ecol Prog Ser 352:39-52

Bendtsen J, Gustafson KE, Rysgaard S, Vang T (2007) Physical conditions, dynamics and model simulations during the ice-free period of the Young Sound/Tyrolerfjord system. In: Rysgaard S, Glud RN (eds) Carbon cycling in Arctic marine ecosystems: case study Young Sound. Medd Grønl Biosci 58:45-61

> Berggreen U, Hansen B, Kiørboe T (1988) Food size spectra, ingestion and growth of the copepod Acartia tonsa during development: implications for determination of copepod production. Mar Biol 99:341-352

Braman RS, Hendrix SA (1989) Nanogram nitrite and nitrate 
determination in environmental and biological materials by vanadium (III). Reduction with chemiluminescense detection. Anal Chem 61:2715-2718

Buch E (1990) A monograph on the physical environment of the Greenland waters. Greenland Fisheries Research Institute, Copenhagen

Falk-Petersen TS, Pavlov V, Sargent JR (2007) Climate variability and possible effects on arctic food chains: the role of Calanus. In: Ørbek JB, Kallenborn R, Tombre I, Nøst Hegeseth E, Falk-Petersen S, Hoel AH (eds) Arctic-alpine ecosystems and people in a changing environment. Part 2. Environment challenges in Arctic-alpine regions. Springer, Berlin, p 433

Fenchel T (1982) Ecology of heterotrophic microflagellates. IV. Quantitative occurrence and importance as bacterial consumers. Mar Ecol Prog Ser 9:35-42

> Fleminger A, Hulsemann K (1977) Geographical range and taxonomic divergence in North Atlantic Calanus (C. helgolandicus, C. finmarchicus and C. glacialis). Mar Biol 40: 233-248

Frost BW (1972) Effects of size and concentration of food particles on the feeding behavior of the marine planktonic copepod Calanus pacificus. Limnol Oceanogr 17:805-815

Grasshoff K, Ehrhardt M, Kremling K (1983) Methods of seawater analysis. Verlag Chemie, Weinheim

> Hanna E, Huybrechts P, Steffen K, Cappelen J and others (2008) Increased runoff from melt from the Greenland Ice Sheet: a response to global warming. J Clim 21:331-341

Hansen PJ, Bjørnsen PK, Hansen BW (1997) Zooplankton grazing and growth: scaling within the $2-2,000-\mu \mathrm{m}$ body size range. Limnol Oceanogr 42:687-704

Heide-Jørgensen MP, Simon MJ, Laidre KL (2007) Estimates of large whale abundance in Greenlandic waters from a ship-based survey in 2005. J Cetacean Res Manag 9: 95-104

> Hirche HJ (1991) Distribution of dominant calanoid copepod species in the Greenland Sea during late fall. Polar Biol 11:351-362

Hirst AG, Bunker AJ (2003) Growth of marine planktonic copepods: global rates and patterns in relation to chlorophyll a, temperature, and body weight. Limnol Oceanogr 48:1988-2010

Holland DM, Thomas RH, Young BD, Ribergaard $\mathrm{MH}$, Lyberth B (2008) Acceleration of Jakobshavn Isbræ triggered by warm subsurface ocean waters. Nature Geosci 1:659-664

Hop H, Pearson T, Hegeseth EN, Kovacs KM and others (2002) The marine ecosystem of Kongsfjorden, Svalbard. Polar Res 21:167-208

Juul-Pedersen T, Nielsen TG, Michel C, Møller EF and others (2006) Sedimentation following the spring bloom in Disko Bay, West Greenland, with special emphasis on the role of copepods. Mar Ecol Prog Ser 314:239-255

Kattsov VM, Källén E (2005) Future climate change: modelling and scenarios for the Arctic. In: Symon C, Arris L, Heal B (eds) Arctic climate impact assessment. Cambridge University Press, Cambridge, p 99-150

Kiørboe T, Møhlenberg F, Riisgård HU (1985) In situ feeding rates of planktonic copepods: a comparison of four methods. J Exp Mar Biol Ecol 88:67-81

Levinsen H, Nielsen TG (2002) The trophic role of marine pelagic ciliates and heterotrophic dinoflagellates in arctic and temperate coastal ecosystems: a cross-latitude comparison. Limnol Oceanogr 47:427-439

> Levinsen H, Jefferson TT, Nielsen TG, Hansen BW (2000) On the trophic coupling between protists and copepods in arctic marine ecosystems. Mar Ecol Prog Ser 204: $65-77$

> Marshall SM, Orr AP (1955) On the biology of Calanus finmarchicus. VIII. Food uptake, assimilation and excretion in adult stage V Calanus. J Mar Biol Assoc UK 34:495-529

Menden-Deuer S, Lessard EJ (2000) Carbon to volume relationships for dinoflagellates, diatoms, and other protist plankton. Limnol Oceanogr 45:569-579

> Merkel F, Mosebech D, Boertmann D, Grøndahl L (2002) Winter seabird distribution and abundance off south-western Greenland, 1999. Polar Res 21:17-36

Meyer-Harms B, Irigoien X, Head R, Harris R (1999) Selective feeding on natural phytoplankton by Calanus finmarchicus before, during, and after the 1997 spring bloom in the Norwegian Sea. Limnol Oceanogr 44:154-165

> Møller EF, Nielsen TG, Richardson K (2006) The zooplankton community in the Greenland Sea: composition and role in carbon turnover. Deep-Sea Res Part I 53:76-93

> Munk P, Hansen BW, Nielsen TG, Thomsen HA (2003) Changes in plankton and fish larvae communities across hydrographic fronts off West Greenland. J Plankton Res 25:815-830

> Pedersen SA, Smidt ELB (2000) Zooplankton distribution and abundance in west Greenland waters, 1950-1984. J Northwest Atl Fish Sci 26:45-102

> Pedersen SA, Ribergaard MH, Simonsen CS (2005) Microand mesozooplankton in Southwest Greenland waters in relation to environmental factors. J Mar Syst 56:85-112

> Riebesell U, Reigstad M, Wassmann P, Noji T, Passow U (1995) On the trophic fate of Phaeocystis pouchetii (Hariot): VI. Significance of Phaeocystis-derived mucus for vertical flux. Neth J Sea Res 33:193-203

> Rignot E, Kanagaratnam P (2006) Changes in the velocity structure of the Greenland Ice Sheet. Science 311: 986-990

Rivkin RB, Legendre L (2001) Biogenic carbon cycling in the upper ocean: effects of microbial respiration. Science 291: 2398-2400

Rysgaard S, Glud RN (2004) Anaerobic $\mathrm{N}_{2}$ production in Arctic sea ice. Limnol Oceanogr 49:86-94

Rysgaard S, Glud RN (2007) Carbon cycling and climate change: predictions for a High Arctic marine ecosystem (Young Sound, NE Greenland). In: Rysgaard S, Glud RN (eds) Carbon cycling in Arctic marine ecosystems: case study Young Sound. Medd Grønl Biosci 58:205-214

> Rysgaard S, Vang T, Stjernholm M, Rasmussen B, Windelin A, Kiilsholm S (2003) Physical conditions, carbon transport, and climate change impacts in a northeast Greenland fjord. Arct Antarct Alp Res 35:301-312

Rysgaard S, Arendt K, Frederiksen M, Mortensen J and others (2008) Nuuk Basic: the MarineBasic programme 2005-2006. In: Klitgaard AB, Rasch M, Caning K (eds) Nuuk Ecological Research Operations, 1st Annual Report 2008, Danish Polar Centre, Copenhagen, p 38-73

Satapoomin S (1999) Carbon content of some common tropical Andaman Sea copepods. J Plankton Res 21:2117-2123

Smidt ELB (1979) Annual cycles of primary production and of zooplankton at Southwest Greenland. Greenl Biosci 1: $3-53$

> Sommer U, Lengfellner K (2008) Climate change and the timing, magnitude, and composition of the phytoplankton spring bloom. Glob Change Biol 14:1199-1208

Steeman-Nielsen E (1952) The use of radio-active carbon (14C) for measuring organic production in the sea. J Cons Int Explor Mer 18:117-140

Strickland JHD, Parsons TR (1972) A practical handbook of 
seawater analysis. Fish Res Board Canada, Ottawa

Thor P, Nielsen TG, Tiselius P, Juul-Pedersen T and others (2005) Post-spring bloom community structure of pelagic copepods in the Disco Bay, West Greenland. J Plankton Res 27:341-356

Velicogna I, Wahr J (2006) Acceleration of Greenland ice mass loss in spring 2004. Nature 443:329-331

Editorial responsibility: Katherine Richardson, Copenhagen, Denmark
Verity GP, Wassmann P, Frischer ME, Howard-Jones MH, Allen AE (2002) Grazing of phytoplankton by microzooplankton in the Barents Sea during early summer. J Mar Syst 38:109-123

Zweng MM, Münchow A (2006) Warming and freshening of Baffin Bay, 1916-2003. J Geophys Res 111:C07016. doi: 10.1029/2005JC003093

Submitted: February 11, 2009; Accepted: October 12, 2009 Proofs received from author(s): February 15, 2010 